\title{
Maternal-Fetal Fat Transport Versus New Fat Synthesis in the Pregnant Diabetic Rat
}

\author{
E. Shafrir and S. Khassis \\ Department of Clinical Biochemistry, Hadassah University Hospital and Hebrew University-Hadassah Medical School, \\ Jerusalem, Israel
}

\begin{abstract}
Summary. Rats were made diabetic by the injection of streptozotocin on day 12 of pregnancy and were investigated on days 17 and 20 of pregnancy. A significant correlation between both maternal plasma triglyceride and nonesterified fatty acid levels with placental or fetal triglyceride content was found, although fetal weight did not change significantly. In order to investigate the source of the placental and fetal fat the rats received, intragastrically $24 \mathrm{~h}$ earlier, $1-{ }^{14} \mathrm{C}$-triolein (as a preformed fatty acid tracer) and tritiated water (as a marker of de novo fatty acid synthesis). Several maternal tissues, placenta, and fetuses were extracted and analysed for fatty acid radioactivity. Compared with non-diabetic pregnant rats, maternal ${ }^{14} \mathrm{C}$ label storage was reduced. In contrast, the placental and fetal tissues demonstrated a significant rise in ${ }^{14} \mathrm{C}$ label, similar in magnitude to the rise in their triglyceride content. The pattern of ${ }^{3} \mathrm{H}$ incorporation also indicated a pronounced decrease in maternal fatty acid synthesis, but no increase in de novo fatty acid synthesis in the fetus or placenta. The findings show that fetal lipids in the pregnant rat originate both from maternal fatty acids and those synthesized in situ. The diabetes-induced increment in fetal triglyceride content is derived, however, from preformed maternal triglycerides or non-esterified fatty acids secondary to the increase in their concentration in the maternal circulation.
\end{abstract}

Key words: Placenta, fetus, pregnancy, diabetes, triglycerides, non-esterified fatty acids.

Two hypotheses have been advanced in order to explain fetal macrosomia in the offspring of diabetic mothers. Pedersen [1], knowing that maternal hyperglycaemia is transferable across the placenta, has suggested that this leads to fetal pancreatic islet stimulation producing hyperinsulinism which in turn promotes fetal tissue growth by enhancing protein, carbohydrate and lipid synthesis. With respect to fetal lipid accumulation, Szabo and Szabo [2] proposed that the high levels of non-esterified fatty acids (NEFA) in the maternal circulation create a steep concentration gradient across the placenta which may accelerate their transport and deposition as triglycerides (TG) in fetal tissues.

Placental lipid transport has been investigated extensively (for reviews 3-6). On the basis of labelled tracer studies, umbilical cord arteriovenous gradients, placental perfusion and the presence of essential fatty acids in the fetus, ample evidence has been produced that in man, as in other species, a substantial amount of fetal lipids is supplied by the mother.

To explore the possibility that in maternal hyperlipidaemia there may be an accelerated transfer of lipids, we have used the rat model and correlated the levels of both TG and NEFA in the maternal circulation with the TG content of placentas and fetuses in streptozotocin diabetes induced during the gestation. In order to assess the relative quantities of maternal and fetal synthesis of fatty acids in diabetic pregnancy, we have administered to the mother two labels: $1-{ }^{14} \mathrm{C}$-oleate as triolein to trace the distribution of preformed fatty acids upon their physiological absorption, and ${ }^{3} \mathrm{H}_{2} \mathrm{O}$ to follow new synthesis of fatty acids. ${ }^{3} \mathrm{H}_{2} \mathrm{O}$ distributes uniformly in the body water and tritium label incorporation is a measure of lipogenesis de novo since it results in a random NADHand NADPH-mediated incorporation of hydrogen atoms along the fatty acid carbon chain during its formation [7]. 
Table 1. Glucose levels and relative tissue weights in the pregnant diabetic and control rats

\begin{tabular}{|c|c|c|c|c|}
\hline & \multicolumn{2}{|c|}{ Pregnancy (day 17) } & \multicolumn{2}{|c|}{ Pregnancy (day 20) } \\
\hline & $\begin{array}{l}\text { Control } \\
(n=10)\end{array}$ & $\begin{array}{l}\text { Diabetes } \\
(n=10)\end{array}$ & $\begin{array}{l}\text { Control } \\
(n=14)\end{array}$ & $\begin{array}{l}\text { Diabetes } \\
(n=18)\end{array}$ \\
\hline Rat weight (g) & $277 \pm 10$ & $252 \pm 11$ & $286 \pm 11$ & $276 \pm 12$ \\
\hline Maternal liver $(\mathrm{g} / 100 \mathrm{~g})$ & $4.04 \pm 0.08$ & $4.11 \pm 0.14$ & $4.14 \pm 0.13$ & $4.22 \pm 0.08$ \\
\hline Maternal adipose tissue ${ }^{\mathrm{a}}(\mathrm{g} / 100 \mathrm{~g})$ & $2.88 \pm 0.21$ & $1.74 \pm 0.08^{\mathrm{c}}$ & $3.25 \pm 0.33$ & $1.20 \pm 0.15^{c}$ \\
\hline Maternal plasma glucose, $(\mathrm{mmol} / \mathrm{l})$ & $5.0 \pm 0.2$ & $23.5 \pm 1.7^{\mathrm{c}}$ & $5.8 \pm 0.3$ & $26.0 \pm 1.3^{\circ}$ \\
\hline Number of fetuses & $9.1 \pm 0.6$ & $9.6 \pm 0.7$ & $9.5 \pm 0.5$ & $9.3 \pm 0.4$ \\
\hline Placental weight ${ }^{\mathrm{b}}:$ total $(\mathrm{g})$ & $3.08 \pm 0.19$ & $2.78 \pm 0.20$ & $3.88 \pm 0.22$ & $4.05 \pm 0.18$ \\
\hline single $(\mathrm{mg})$ & $339 \pm 14$ & $290 \pm 19$ & $408 \pm 19$ & $436 \pm 19$ \\
\hline \multirow{2}{*}{$\begin{array}{l}\text { total (g) } \\
\text { single (mg) }\end{array}$} & $5.06 \pm 0.56$ & $4.18 \pm 0.47$ & $17.68 \pm 1.26$ & $20.19 \pm 1.18$ \\
\hline & $556 \pm 71$ & $435 \pm 50$ & $1860 \pm 268$ & $2170 \pm 205$ \\
\hline
\end{tabular}

a Combined parametrial and perirenal adipose tissues.

b Five placentas and fetuses from each litter were weighed and their weights averaged.

c Statistically significant difference at $p<0.01$ or less (diabetes versus control).

Results are expresend as mean \pm SEM for the indicated number of rats

\section{Materials and Methods}

\section{Animals and Assays}

Pregnant albino rats of the Hebrew University strain were used and were fed a regular chow ad libitum. Females and males were caged together for one night from 17.00 to $07.00 \mathrm{~h}$. Diabetes was induced in the pregnant rats on day 12 by IP injection of streptozotocin $65 \mathrm{mg} / \mathrm{kg}$, freshly dissolved in citrate buffer $5 \mathrm{mmol} / 1(\mathrm{pH} 4.5)$.

Groups of rats were sacrificed on days 17 and 20 of pregnancy. For the sake of uniformity, only rats with litters of $8-11$ fetuses were used in the experiments. Blood was taken for the determination of maternal plasma levels of glucose (hexokinase method), TG (kinetic, fully enzymatic lipase-glycerokinase ultraviolet method) cholesterol (cholesterol oxidase method) and NEFA [8]. The enzymatic determinations were carried out with the reagents and procedures of Boehringer (Mannheim, FRG) using a Centrifichem centrifugal analyser.

The placental and fetal TG and cholesterol contents were also determined. The tissues were extracted in chloroform:methanol $(2: 1, \mathrm{v} / \mathrm{v})$. A portion of the extract was evaporated and the TG-glycerol determined enzymatically after alkaline hydrolysis, using the reagents of Boehringer in a Centrifichem analyser. Cholesterol was similarly determined by the enzymatic assay of Boehringer, after solubilization of the cholesterol in water. This was achieved by adding Triton X-100, $2.5 \mathrm{mg} / \mathrm{ml}$, to another portion of the extract before evaporation.

\section{Radioactive Tracer Studies}

In order to determine the origin of fetal lipids, on days 16 or 19 of pregnancy, groups of rats received, via a stomach tube, exactly $0.5 \mathrm{ml}$ of ${ }^{3} \mathrm{H}_{2} \mathrm{O}(10 \mathrm{mCi})$ and $0.5 \mathrm{ml}$ of glycerol-[ $\left[1-{ }^{14} \mathrm{C}\right]$-trioleate $(50 \mu \mathrm{Ci}$ and $50 \mu \mathrm{mol})$ emulsified by sonication in $0.2 \mathrm{~mol} / 1$ Tris$\mathrm{HCl}$ buffer ( $\mathrm{pH} 8.0$ ), containing albumin $5 \mathrm{mg} / \mathrm{ml}$ and Triton $\mathrm{X}$ $1002.5 \mathrm{mg} / \mathrm{ml}$. The radiocative materials were purchased from the Radiochemical Centre, Amersham, UK.

The animals were lightly anaesthetised with ether $24 \mathrm{~h}$ later. After laparotomy, the maternal blood was collected into an heparinised syringe from the abdominal aorta, the maternal liver and parametrial-perirenal adipose tissues were removed. All placentas and fetuses were separated, thoroughly rinsed in cold $0.9 \% \mathrm{NaCl}$ solution and five of each weighed. The fetal livers, from each litter were separated and pooled.

The plasma and tissues were extracted in chloroform-methanol $(2: 1, \mathrm{v} / \mathrm{v})$, the extracts were separated into two phases and the lower phase washed three times with a synthetic upper phase containing $0.05 \% \mathrm{MgCl}_{2}$, as recommended by Folch et al. [9]. Portions of the washed extracts were evaporated and the lipid hydrolysed by heating for $60 \mathrm{~min}$ at $70^{\circ} \mathrm{C}$ with potassium hydroxide $5 \mathrm{~mol} / 1$ in ethanol $(1: 7, \mathrm{v} / \mathrm{v})$. After removing the unsaponifiable lipids by shaking twice with petroleum ether, the saponified fatty acids were transferred from the ethanolic phase into heptane by acidification of the mixture and vigorous shaking for $2 \mathrm{~min}$. The fatty acid radioactivity in heptane was determined, after evaporation, in a liquid scintillation spectrometer.

\section{Results}

Table 1 shows the main characteristics of the pregnant control and diabetic groups of rats with particular relation to glucose levels and tissue weights. As expected, the diabetic rats had a marked hyperglycaemia and lost considerable amounts of adipose tissue during the 5 or 8 days after the onset of diabetes. There was no significant difference in the relative liver size, or in the weight of placentas and fetuses, between the diabetic and control groups, although the diabetic placentas and fetuses were slightly smaller on day 17 and slightly larger on day 20 of pregnancy.

\section{Relationship Between Concentration of Lipids in the Maternal Plasma and in Fetoplacental Tissues}

The plasma and tissue lipid values are given in Table 2. The mean maternal TG levels in the diabetic rats exceeded those of control rats by about 1.8 times on day 
Table 2. Plasma and tissue lipid values in pregnant diabetic rats

\begin{tabular}{|c|c|c|c|c|}
\hline & \multicolumn{2}{|c|}{ Pregnancy (day 17) } & \multicolumn{2}{|c|}{ Pregnancy (day 20) } \\
\hline & $\begin{array}{l}\text { Control } \\
(n=10)\end{array}$ & $\begin{array}{l}\text { Diabetes } \\
(n=10)\end{array}$ & $\begin{array}{l}\text { Control } \\
(n=14)\end{array}$ & $\begin{array}{l}\text { Diabetes } \\
(n=18)\end{array}$ \\
\hline \multicolumn{5}{|l|}{ Maternal plasma } \\
\hline Triglycerides (mmol/1) & $2.80 \pm 0.32$ & $4.96 \pm 0.62^{\mathrm{a}}$ & $3.06 \pm 0.17$ & $7.23 \pm 0.55^{\mathrm{a}}$ \\
\hline $\mathrm{NEFA}(\mu \mathrm{mol} / \mathrm{l})$ & $606 \pm 57$ & $997 \pm 81^{\mathrm{a}}$ & $695 \pm 47$ & $1279 \pm 108^{a}$ \\
\hline Cholesterol $(\mathrm{mmol} / \mathrm{l})$ & $1.38 \pm 0.05$ & $2.04 \pm 0.18^{\mathrm{a}}$ & $1.45 \pm 0.05$ & $2.28 \pm 0.16^{\mathrm{a}}$ \\
\hline \multicolumn{5}{|l|}{ Placental triglycerides } \\
\hline All placentas /litter $(\mu \mathrm{mol})$ & $12.75 \pm 1.20$ & $21.19 \pm 2.12^{a}$ & $18.25 \pm 1.55$ & $35.14 \pm 2.46^{\mathrm{a}}$ \\
\hline$(\mu \mathrm{mol} / \mathrm{g})$ & $4.13 \pm 0.23$ & $7.63 \pm 0.64^{\mathrm{a}}$ & $4.71 \pm 0.30$ & $8.68 \pm 0.50^{a}$ \\
\hline \multicolumn{5}{|l|}{ Fetal triglycerides } \\
\hline All fetuses/litter $(\mu \mathrm{mol})$ & $9.10 \pm 1.00$ & $12.68 \pm 1.22$ & $31.32 \pm 2.61$ & $58.94 \pm 0.23^{\mathrm{a}}$ \\
\hline$(\mu \mathrm{mol} / \mathrm{g})$ & $1.80 \pm 0.21$ & $3.02 \pm 0.28^{\mathrm{a}}$ & $1.77 \pm 0.12$ & $2.92 \pm 0.23^{\mathrm{a}}$ \\
\hline
\end{tabular}

Results expresed as mean $\pm \mathrm{SEM}$.

${ }^{a}$ statistically significant difference at $p<0.01$ or less (diabetes versus control)

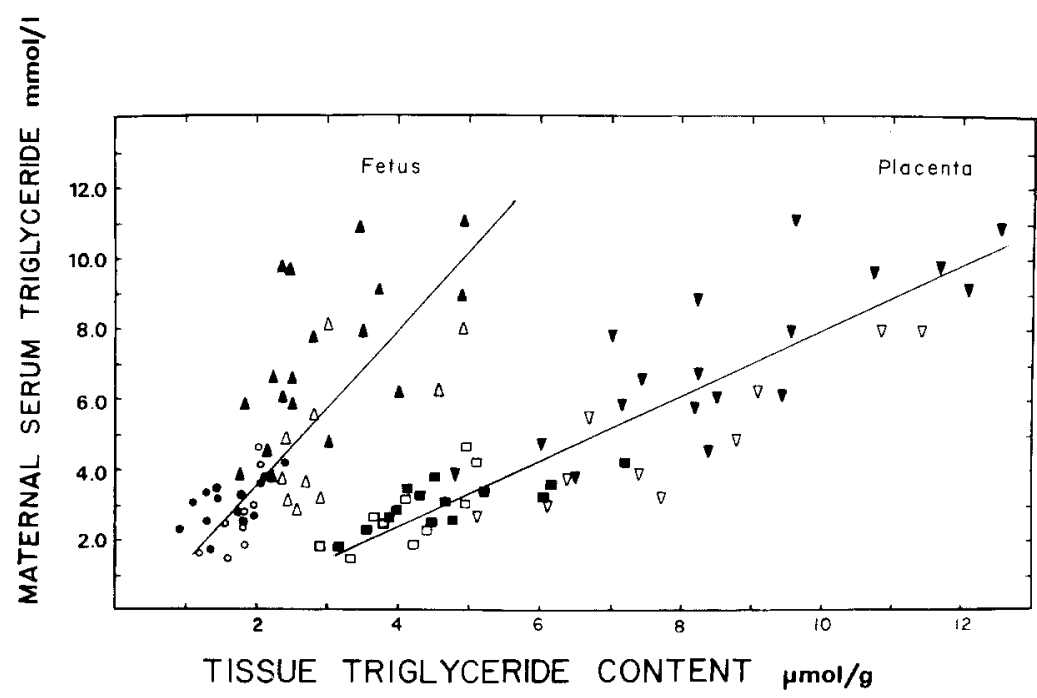

Fig. 1. Relationship between the triglyceride concentration in the maternal circulation and the triglyceride content in placentas and fetuses. $O$ control and $\triangle$ diabetic rat fetal TG on day 17 ; - control and $\Delta$ diabetic rat fetal TG on day 20; $\square$ control and $\nabla$ diabetic rat placental TG on day 17; $\boldsymbol{\square}$ control and $\boldsymbol{\nabla}$ diabetic rat placental TG on day 20; Regression lines: for placentas: $y=$ $-1.05+0.89 \times ; r=0.88$; for fetuses: $y=-0.45$ $+2.11 \times ; r=0.74$; Each value is a mean of five placentas or five fetuses from each of the 52 litters
17 and by about 2.4 times on day 20 of pregnancy. NEFA levels were also increased but somewhat less markedly, and the increases in plasma cholesterol were comparatively moderate.

Placental TG significantly increased in the diabetic rats both in terms of the total amount deposited in the tissue of the whole litter, as well as per gram of placenta. The mean increase on day 17 was about 1.7 times and on day 20 about 1.9 times.

The TG content of the fetuses of diabetic rats increased by a somewhat lesser extent. On day 17 the mean TG content per gram fetal tissue exceeded that of control rats by about 1.7 times and was highly significant. The TG content per total litter was higher by about 1.4 times and was significant only at $p<$ 0.05 . On day 20 of pregnancy the increases in fetal TG were more marked both per litter and per gram (1.6-2.0 times) and were all highly significant.

There was a significant correlation between the level of circulating TG in the maternal plasma and placental and fetal tissue TG content when the individual values were plotted (Fig. 1). The increase in placental TG content in relation to maternal plasma TG levels was more pronounced than that of fetal TG content.

A plot between maternal plasma NEFA and placental and fetal TG, similar to that shown in Fig. 1, was also constructed. A linear relationship was obtained: $y=2+137 \mathrm{x}, r=0.86$ for the placenta and $y=310+247 \mathrm{x}, r=0.53$ for the fetus (scattergram not shown). 

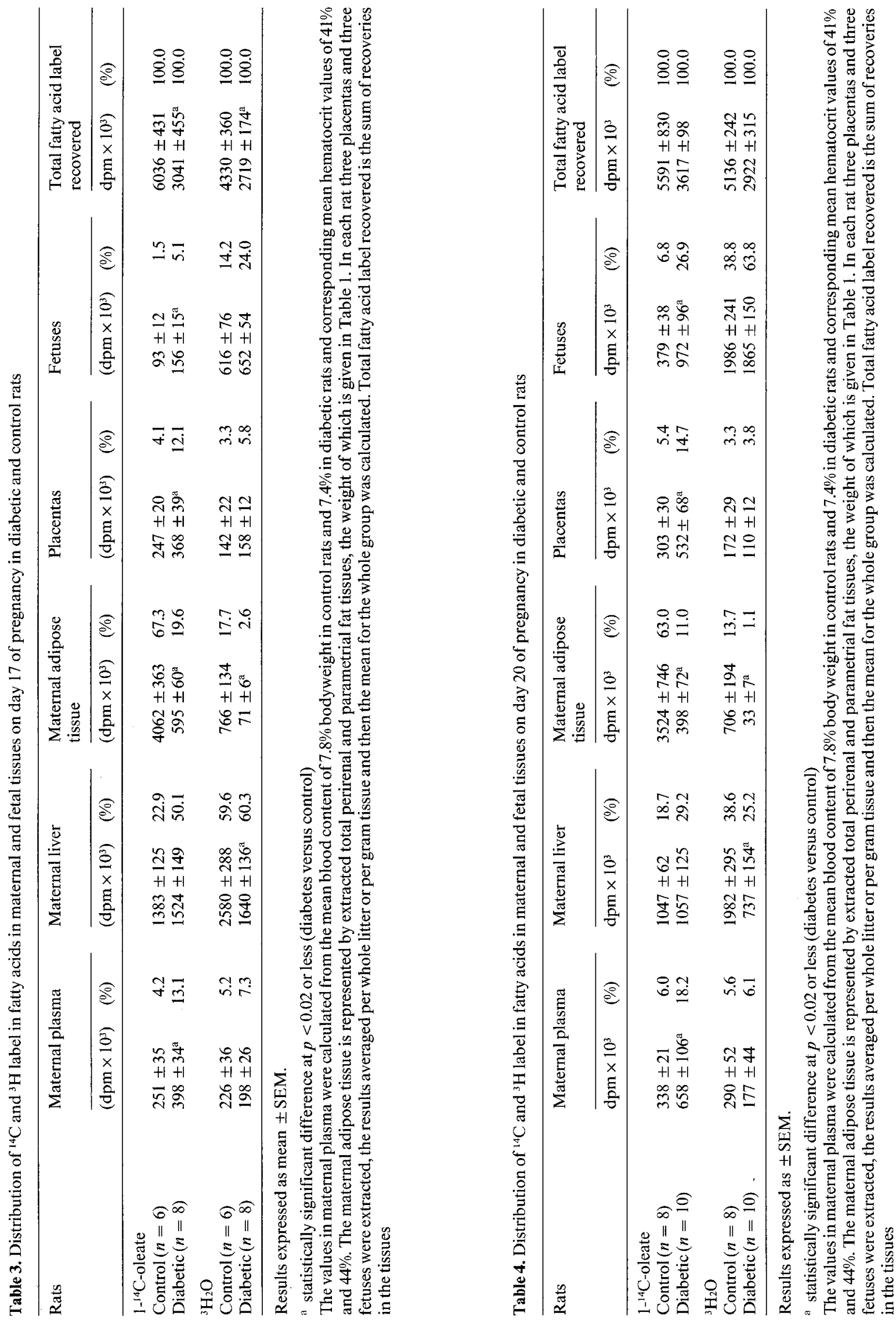
Table 5. Distribution of fatty and radioactivity in the fetus

\begin{tabular}{|c|c|c|c|c|}
\hline & \multicolumn{2}{|c|}{ Pregnancy (day 17) } & \multicolumn{2}{|c|}{ Pregnancy (day 20) } \\
\hline & $\begin{array}{l}\text { Control } \\
(n=6)\end{array}$ & $\begin{array}{l}\text { Diabetes } \\
(n=8)\end{array}$ & $\begin{array}{l}\text { Control } \\
(n=8)\end{array}$ & $\begin{array}{l}\text { Diabetes } \\
(n=10)\end{array}$ \\
\hline Fetal liver (mg/100 mg fetus) & $7.68 \pm 0.31$ & $7.53 \pm 0.28$ & $6.30 \pm 0.17^{\mathrm{a}}$ & $6.20 \pm 0.24^{\mathrm{a}}$ \\
\hline Liver triglyceride content $(\mu \mathrm{mol})$ & $1.76 \pm 0.28$ & $2.92 \pm 0.36^{\mathrm{b}}$ & $7.08 \pm 0.65$ & $14.30 \pm 0.98^{\mathrm{b}}$ \\
\hline$\%$ of fetus & $19.4 \pm 1.7$ & $23.0 \pm 1.8$ & $22.6 \pm 2.0$ & $24.3 \pm 1.6$ \\
\hline $\begin{array}{l}{ }^{14} \mathrm{C} \text {-oleate radioactivity } \\
\text { fetus, total }\left(\mathrm{dpm} \times 10^{3}\right) \\
\% \text { in liver }\end{array}$ & $\begin{array}{c}93 \pm 12 \\
24.2 \pm 2.2\end{array}$ & $\begin{array}{r}156 \pm 15^{\mathrm{b}} \\
18.8 \pm 1.5\end{array}$ & $\begin{array}{c}379 \pm 39 \\
14.8 \pm 1.0^{\mathrm{a}}\end{array}$ & $\begin{array}{c}972 \pm 96^{\mathrm{b}} \\
12.4 \pm 2.2^{\mathrm{a}}\end{array}$ \\
\hline $\begin{array}{l}{ }^{3} \mathrm{H} \text { radioactivity } \\
\text { fetus, total, }\left(\mathrm{dpm} \times 10^{3}\right) \\
\% \text { in liver }\end{array}$ & $\begin{array}{c}616 \pm 76 \\
21.4 \pm 2.5\end{array}$ & $\begin{array}{c}652 \pm 54 \\
17.3 \pm 1.9\end{array}$ & $\begin{array}{c}1986 \pm 241 \\
11.2 \pm 0.9^{\mathrm{a}}\end{array}$ & $\begin{array}{r}1865 \pm 150 \\
8.9 \pm 1.1^{a}\end{array}$ \\
\hline
\end{tabular}

Results are expressed mean \pm SEM

${ }^{a}$ significant difference in the liver share between days 17 and 20 of pregnancy at the level of $p<0.05$ or less

${ }^{b}$ significant difference between control and diabetic rats on any day of pregnancy at $p<0.05$ or less

\section{Distribution of ${ }^{14} \mathrm{C}$-oleate and ${ }^{3} \mathrm{H}_{2} \mathrm{O}$ Label in the Fatty Acids of Maternal and Fetoplacental Tissues}

The distribution of ${ }^{14} \mathrm{C}$ and ${ }^{3} \mathrm{H}$ tracers, $24 \mathrm{~h}$ after the administration to the mother, is recorded in Tables 3 and 4 . Since the results on days 17 and 20 of pregnancy are qualitatively similar, they are described together below.

The total amount of the oleate-derived ${ }^{14} \mathrm{C}$-label, which was recovered in a few representative tissues, was lower in the diabetic compared with control rats. This was due to the particularly low amount of label deposited in maternal adipose tissue, reflecting its 'lipolytic' rather than 'lipogenic' status. The ${ }^{14} \mathrm{C}$-label in maternal liver and plasma was higher in the diabetic rats both in terms of amount and percentage of the total recovered radioactivity, probably as a result of enhanced transport and oxidation of fatty acids in diabetes.

With respect to the ${ }^{3} \mathrm{H}$-label, the total recovery was also substantially lower in diabetic than control rats. The very low amount of ${ }^{3} \mathrm{H}$ found in maternal adipose tissue is in accord with the greatly reduced fatty acid synthetic capacity in diabetes. The amount of ${ }^{3} \mathrm{H}$ in maternal plasma and liver fatty acids was lower in diabetic compared with non-diabetic rats, unlike the findings with ${ }^{14} \mathrm{C}$, reflecting their diminished availability.

In fetal and placental tissues, the amount of ${ }^{14} \mathrm{C}$ labelled fatty was significantly higher in the diabetic than control rats, unlike the findings on the maternal side (Tables 3 and 4). This was evident both in the amount and percentage of ${ }^{14} \mathrm{C}$ recovered in these tissues. The increment of ${ }^{14} \mathrm{C}$ in the fetuses of diabetic rats exceeded that in the placentas, particularly on day 20 of pregnancy. The amount of ${ }^{14} \mathrm{C}$-label in the placentas increased by approximately 1.5 and 1.7 times on days 17 and 20 of pregnancy, whereas it rose in the fetuses by approximately 1.7 and 2.6 times on the corresponding days. By percentage of the total radioactivity, the rise in placentas and fetuses was three to four times higher in the diabetic than in the control rats on both days of pregnancy.

The amount of ${ }^{3} \mathrm{H}$-labelled fatty acids present in the placentas and fetuses was not significantly different in diabetic versus control rats, contrary to the findings with the ${ }^{14} \mathrm{C}$-oleate label. This indicates that there was no increase in new fatty acid synthesis in diabetes, but two observations should be considered in this respect.

1) The amount of ${ }^{3} \mathrm{H}$-label both in control and diabetic placentas and fetuses in relation to the sum of ${ }^{3} \mathrm{H}$ label in maternal liver, plasma and adipose tissue was large and increased with gestation. This may be illustrated by the fetal/maternal ${ }^{3} \mathrm{H}$ ratio which was 0.21 on day 17 and rose to 0.75 on day 20 of pregnancy in the control rats (calculated from the values of Tables 3 and 4). This rise was mainly due to the increased content of ${ }^{3} \mathrm{H}$-labelled fatty acids in the fetus. In the diabetic rats the fetal/maternal ${ }^{3} \mathrm{H}$ ratio was even higher: 0.42 on day 17 and 0.95 on day 20 of pregnancy. Similar fetal/maternal ratios in the case of ${ }^{14} \mathrm{C}$-labelled fatty acids were much lower: 0.06 and 0.12 on days 17 and 20 of pregnancy in control rats and 0.21 and 0.71 respectively in diabetic rats.

2) The incorporation of ${ }^{3} \mathrm{H}$ into the placental and fetal fatty acids, although not different in amount in control and diabetic rats, occurred in the latter in the face of diminished total ${ }^{3} \mathrm{H}$-label recovery. Thus, the percentage of ${ }^{3} \mathrm{H}$ incorporated into the fetuses of diabetic rats was higher: 24.0 versus $14.2 \%$ of total on day 17 and 63.8 versus $38.8 \%$ of total on day 20 of 
pregnancy. It could be construed, therefore, that while the total amount of ${ }^{3} \mathrm{H}$ incorporated was similar, fatty acid synthesis was actually higher in diabetes if it occurred from a pool of lower precursor specific activity. This possibility proved, however, unlikely by the measurement of the specific activity of ${ }^{3} \mathrm{H}$ in maternal plasma water at sacrifice. In 14 rats the mean \pm SEM values were $717 \pm 32$ and $636 \pm 38 \mathrm{dpm} / \mu \mathrm{g}$ atom $\mathrm{H}$ in control and diabetic rats respectively. Although the specific activity in diabetes was lower by about $11 \%$, the difference was not significant.

To see whether there is a particular site of uptake of the label in the fetus, fetal livers were isolated. This organ constituted between $6 \%$ and $8 \%$ of the fetal body weight and its TG content amounted to as much as $19 \%-24 \%$ of the total fetal TG on days 17 and 20 of pregnancy (Table 5). The deposition of ${ }^{14} \mathrm{C}$-fatty acids or the synthesis of ${ }^{3} \mathrm{H}$-labelled fatty acids in fetal liver was commensurate to the proportion of fetal TG in the liver on day 17 of pregnancy but significantly lower in the liver on day 20 of pregnancy. Evidently the extrahepatic fetal tissues assumed a higher capacity of fat uptake and/or synthesis with advancing pregnancy. Diabetes did not produce significant changes in the relative liver weight, TG content or the share of TG label on both days of pregnancy.

\section{Discussion}

Fat transport through the placenta has been studied in several animal models using radioactive tracers. Substantial and rapid rates of passage, within minutes after maternal administration of NEFA have been demonstrated in guinea pigs $[10,11]$ and rabbits $[12$, 13]. On the other hand, infusion of NEFA into sheep at term led to negligible transfer to the fetal side [14]. The rat appears to show an intermediate rate of placental fat passage. In 1964 [15], when ${ }^{14} \mathrm{C}$-labelled NEFA were injected into the rat abdominal artery on days $17-19$ of pregnancy, only $2 \%-4 \%$ of the label was recovered in esterified form in the placenta and fetus. This small percentage led us then to believe that transport of preformed fatty acids is of minor importance but, on reconsideration these fatty acids may be of cumulative importance over a longer period, especially in diabetic hyperlipidaemia. In 1974 Hummel et al. [16] obtained similar passage rates in confirmatory experiments using ${ }^{14} \mathrm{C}$-palmitate in non-diabetic rats on day 21 of pregnancy. With the aid of compartmental calculations they concluded that this rate of NEFA transfer may account for as much as three-quarters of the fetal fat increment.

Thus, there is strong evidence for the interdependence of the maternal and fetal fat pools involving both
NEFA and TG, as shown by the passage of emulsified lipids across the human placenta [17]. Our positive correlations of maternal plasma TG and NEFA levels with placental and fetal tissue TG content provide additional support for this contention. The data do not permit, however, a conclusion what lipid is preferentially transported. In the placenta the correlation coefficient was of similar magnitude and significance for NEFA and TG. In the fetus the correlation for TG was higher than for NEFA. The high intercept of the regression line indicated that significant fetal TG deposition occurred at higher maternal elevation in NEFA than in TG, but fetal TG rose more markedly with the continued increase in maternal NEFA. It is most likely that NEFA are first esterified in the placenta in a concentration-dependent fashion, as demonstrated in vitro by Diamant et al. [18]. The placental TG content also rises by uptake of TG from very low density lipoproteins, most probably with the participation of lipoprotein lipase, the activity of which was shown to be present in the rat and human placenta [19]. The fact that placental TG rose more pronouncedly than fetal TG seems obvious, since the placenta is directly exposed to both NEFA and TG in the maternal plasma. Fetal TG content may be better related to placental rather than to maternal lipids.

Fatty acid label recovery on the maternal side after the administration of ${ }^{14} \mathrm{C}$-trioleate and ${ }^{3} \mathrm{H}_{2} \mathrm{O}$ has shown a sharp decrease in diabetes, as expected, mainly due to reduced storage of preformed fat or decreased new synthesis. The ${ }^{3} \mathrm{H}$-incorporation on the fetal side was, on the other hand, quite extensive in comparison to maternal tissues in the control rats, and was not affected by diabetes, indicating that the fatty acid synthesis de novo in the fetoplacental unit was impressive but it did not increase in diabetes. Although fetal plasma insulin levels were not measured here, fetal hyperinsulinaemia may be assumed [20], a condition well known to promote lipogenesis. In previous experiments with similary prepared diabetic rats, we have noted activity increase of several insulindependent lipogenesis enzymes in the fetal liver [21]. It may be suggested, therefore, that the enhanced capacity for fatty acid synthesis was mitigated by endproduct inhibition due to the increased supply of preformed fat.

In the case of ${ }^{14} \mathrm{C}$-oleate, its net increment in the fetoplacental unit was convincingly demonstrated in diabetes. It cannot be ascribed to an increase in the specific activity at the direct source, since the mean maternal plasma TG content rose by 1.8 times in diabetes on day 17 and by 2.4 times on day 20 of pregnancy, quite similar to the corresponding 1.6 and 1.9 -fold increases in ${ }^{14} \mathrm{C}$-oleate radioactivity. Furthermore, the diabetes-induced rise in ${ }^{14} \mathrm{C}$-radioactivity on the fetal 
side was similar to the rise in $\mathrm{TG}$ content. Comparison of the mean increase in tissue TG (placenta + fetus, Table 2), shows that they were of the order of 1.55 and 1.90 on days 17 and 20 of pregnancy respectively, the corresponding increase in the amount of ${ }^{14} \mathrm{C}$ radioactivity being 1.54 and 2.20 (Tables 3 and 4). Thus the fetoplacental ${ }^{14} \mathrm{C}$ increment in diabetes should be attributed to the enhanced transfer of maternal NEFA and/or TG-derived fatty acids, due to their increased concentration.

The rise in fatty acids both with ${ }^{14} \mathrm{C}$ and ${ }^{3} \mathrm{H}$ label in the feto-placental unit as a function of pregnancy duration should also be noted, mainly in the fetus, the ultimate target of fat synthesis and deposition. The time-dependent increment was most pronounced in the case of diabetes-induced influx of ${ }^{14} \mathrm{C}$-oleate.

A question may be posed why the increased maternal fat transport in diabetes did not affect the total fetal weight significantly. Was it a phenomenon dissociated from other influences on fetal growth? The duration of diabetes in the rat model, while satisfactory for demonstrating the cause of fetal fat accumulation, might have been too short to produce weight accretion. Diabetes was induced only on day 12 of pregnancy to avoid the pathological placental and fetal changes frequent when diabetes precedes the conception [22]. In addition, diabetes in our rats was rather severe and it was reported that mild diabetes is associated with increased cell proliferation and fetal weight, whereas severe diabetes results in small fetuses and low DNA polymerase activity [23].

Acknowledgment. Appreciation is expressed to S. Lilling and S. Bonjake for their experimental assistance. E. S. is an Established Investigator of the Chief Scientist's Office, Ministry of Health, Israel.

\section{References}

1. Pedersen J (1977) The pregnant diabetic and her newborn, 2nd edn. Williams \& Wilkins, Baltimore, pp 106-122

2. Szabo AJ, Szabo O (1974) Placental free fatty acid transfer and fetal adipose tissue development: An explanation of fetal adiposity in infants of diabetic mothers. Lancet $2: 498-499$

3. Szabo AJ, Grimaldi RD (1970) The metabolism of the placenta. Adv Metab Disorders 4: 186-228

4. Robertson AF, Sprecher H (1968) A review of placental lipid metabolism and' transport. Acta Paediatr Scand 183 (Suppl): 3-18

5. Hull D, Elphick MC (1979) Evidence for fatty acid transfer across the human placenta. In: Beard RW, Hoet JJ (eds) Preg- nancy metabolism, diabetes and the fetus. Ciba Foundation Symposium, Excerpta Medica, Amsterdam, pp 75-86

6. Hull D, Elphick M (1979) Transfer of fatty acids. In: Chamberlain GVP, Wilkinson AW (eds) Placental transfer. Pitman, London, pp 159-165

7. Foster BW, Bloom B (1963) The synthesis of fatty acids by rat liver slices in tritiated water. $\mathrm{J}$ Biol Chem 238: 882-892

8. Ho RJ (1970) Radiochemical assay of long-chain fatty acids using $68 \mathrm{Ni}$ as tracer. Anal Biochem 36:105-113

9. Folch J, Less M, Sloane-Stanley GH (1951) A simple method for the isolation and purification of total lipids from animal tissues. J Biol Chem 225: 497-509

10. Hershfield MS, Nemeth AM (1968) Placental transport of free palmitic and linoleic acids in the guinea pig. J Lipid Res 9: $460-468$

11. Thomas CR, Lowy C, Bacchus RA, Yeoman DK (1977) Transfer of fatty acid across the guinea pig placenta. Diabetologia 13: 436 (Abstract)

12. Van Duyne CM, Havel RJ, Felts YM (1962) Placental transfer of palmitic acid-1-C $\mathrm{C}^{14}$ in rabbits. Am J Obstet Gynecol 84: 1069-1074

13. Edson JL, Hull D (1975) Evidence for increased fatty acid transfer across the placenta during a maternal fast in rabbits. Biol Neonate 27: 50-55

14. Van Duyne GM, Parker HR, Havel RJ, Holm LW (1960) Free fatty acid metabolism in fetal and newborn sheep. Am J Physiol 199:987-990

15. Koren Z, Shafrir E (1964) Placental transfer of free fatty acids in the pregnant rat. Proc Soc Exp Biol Med 116:411-414

16. Hummel L, Schirrmeister N, Zimmermann T, Wagner H (1974) Studies on the lipid metabolism using $1{ }^{14} \mathrm{C}$-palmitate in fetal rats. Biol Neonate 24: 298-305

17. Elphick MC, Filshie GM, Hull D (1978) The passage of fat emulsion across human placenta. Br J Obstet Gynaecol 85: 610-618

18. Diamant YZ, Diamant S, Freinkel N (1980) Lipid deposition and metabolism in rat placenta during gestation. Placenta 1: 319-325

19. Mallov S, Alousi AA (1965) Lipoprotein lipase activity of rat and human placenta. Proc Soc Exp Biol Med 1 19:301-306

20. Kervran A, Girard JR (1974) Glucose induced increase of plasma insulin in the rat foetus in utero. J Endocrinol 62:545-551

21. Diamant YZ, Shafrir E (1979) Placental enzymes of glycolysis, gluconeogenesis and lipogenesis in the diabetic rat and in starvation. Comparison with maternal and fetal liver. Diabetologia 15:481-485

22. Prager R, Abramovici A, Liban E, Laron Z (1974) Histopathological changes in the placenta of streptozotocin induced diabetic rats. Diabetologia 10: 89-91

23. Kim YS, Jatoi I, Kim Y (1980) Neonatal macrosomia in maternal diabetes. Diabetologia 18:407-411

Received: 30 March 1981

and in revised form: 18 June 1981

Professor E. Shafrir

Department of Clinical Biochemistry

Hadassah University Hospital

P.O. Box 12000

Jerusalem 91120, Israel 